\title{
Bacterial "Masons" at Work with Wastes for Producing Eco-cement
}

\author{
O. A. Cuzman, L. Wittig, F. J. Royo Abancéns, C. Herrera, N. R. Anastasi, and L. Sánchez Alonso
}

\begin{abstract}
Industrial waste is now a global concern, causing environmental and economic harm. Industries are rapidly trying to find a solution, searching for optimal ways to manage waste and to change the most common practices, as landfill or incineration. Industrial waste is a very heavy burden for the environment, where a significant proportion of this industrial waste is attributable to construction and demolition waste. To mitigate these threats, a novel biomimetic technology for enzyme-based microbial carbonate precipitation was tested, converting industrial wastes into an ecological product. Within the European Ecocement project (FP7-Grant 282922), a novel eco-cement product was obtained by recovering valuable resources from different industries such as the dairy industry, cement industry and poultry growing industry. The eco-cement product involves the microbial carbonate precipitation process, via urea hydrolysis, in the presence of Sporosarcina pasteurii, a common soil ureolytic bacterium. This paper presented the general concept of the project and the main obtained results.
\end{abstract}

Index Terms-Cement kiln dust, eco-cement, ecological product, Sporosarcina pasteurii, urease, waste recycling.

\section{INTRODUCTION}

Cement is the essential "glue" in concrete, a fundamental building material for society's infrastructure around the world. Concrete is second only to water in total volumes consumed annually by society [1], [2]. But producing cement also produces $\mathrm{CO}_{2}$, leading the cement industry to produce approximately $5 \%$ of current global man-made $\mathrm{CO}_{2}$ emissions. With climate change mitigation and adaptation measures increasing, concrete demand is expected to increase even further. Particularly, in developing countries, cement production is forecast to grow as modernization and growth continues.

Currently the production of one ton of cement commonly results in the release of 0.65 to 0.95 tons of $\mathrm{CO}_{2}$ depending on

Manuscript received November 5, 2014; revised January 4, 2015. This work was made under the frame of the ECOCEMENT project (FP7- Grant 282922).

O. A. Cuzman is with Institute for the Conservation and Valorization of Cultural Heritage (ICVBC-CNR), Via Madonna del Piano 10, 50019, Sesto Fiorentino, Italy (e-mail: cuzman@icvbc.cnr.it).

L. Wittig is with Fraunhofer-Institut für Fertigungstechnik und Angewandte Materialforschung IFAM, Wiener Straße 12|28359 Bremen, Germany (e-mail: linda.wittig@ifam.fraunhofer.de).

C. Herrera is with Delap and Waller EcoCo, Ireland (e-mail: cherrera715@gmail.com).

F. J. Royo Abancéns is with Solintel, Avda. De la INdustria 32, EP-2, 28108 Alcobendas, Madrid, Spain (e-mail: Javier.royo@solintel.eu).

N. R. Anastasi is with Neapolis University Pafos, Cyprus (e-mail: nra4c@spidernet.com.cy).

L. Sánchez Alonso is with Grupo Essentium, Avenida de Quitapesares, 11 Polígono Empresarial Villapark, 28670 Villaviciosa de Odón, Madrid, Spain (e-mail: lsanchez@essentium.com). the efficiency of the process, fuels used, and specific type of cement product. Considering the scale of the worldwide cement production, even a slight decrease in the average global emissions per ton has a large $\mathrm{CO}_{2}$ reduction potential. Every $10 \%$ decrease in the cement $\mathrm{CO}_{2}$ intensity by 2050 could save around $0.4 \mathrm{Gt} \mathrm{CO}_{2}$, and substantially contribute to slowing down climate change [1], [2]. Further abatement could originate from the more efficient use of cement and concrete. Additionally, innovative low $\mathrm{CO}_{2}$ cementitious materials are to be considered as a reduction measure. The use of waste materials in the cement industry, also referred to as co-processing, contributes towards achieving these objectives.

An attempt to use treatments more in line with the nature of these materials has, in the past few decades, directed attention to biomaterials, generally carbonates, produced by living organisms, particularly bacteria.

Microbial carbonate precipitation has gained interest in the past 20 years particularly with regard to the potential role marine systems may play as "carbon sinks" for the increasing global production of $\mathrm{CO}_{2}$ [3]. The feasibility of microbial calcite precipitation is well established in literature, as a great number of researchers work on these type of processes, from one standpoint or another, [4]-[15].

The medium ingredients in biotechnology processes are a major cost factor, ranging between 10 to $60 \%$ of the total operating costs. The medium cost increases proportionally with the size of the scale up. Because of this, it is important to give consideration to optimization of the medium prior to scale up. Given that biocementation process does not require ease of removal of medium components or use of a defined medium, we are able to look at a range of more economical components to replace the existing expensive analytical grade chemicals.

Reusing industrial by-products as a source of calcium, urea and nutrients for producing eco-cement is discussed in this paper. This alternative waste recycling has dual benefits as it contributes, not only to reduce the process costs, but to minimize environmental impacts associated to the disposal of such wastes.

\section{BIOMINERALIZATION CONCEPT AND WASTE RECYCLING}

\section{A. Biomineralization Concept}

The mechanism of microbial induced calcium carbonate precipitation process (MICCP) involves the ureolytic bacteria that hydrolyze urea to produce bicarbonate ions (1-3), and in the presence of free calcium ions (4), the calcium carbonate will precipitate [8], [11], [13]-[17]. 


$$
\begin{gathered}
\left(\mathrm{NH}_{2}\right)_{2} \mathrm{CO}+2 \mathrm{H}_{2} \mathrm{O} \rightarrow \mathrm{CO}_{2}+2 \mathrm{NH}_{3} \\
2 \mathrm{NH}_{3}+2 \mathrm{H}_{2} \mathrm{O} \rightarrow 2 \mathrm{NH}_{4}^{+}+2 \mathrm{OH}^{-} \\
\mathrm{CO}_{2}+\mathrm{OH}^{-} \rightarrow \mathrm{HCO}_{3}^{-} \\
\mathrm{Ca}^{2+}+\mathrm{HCO}_{3}^{-}+\mathrm{OH}^{-} \rightarrow \mathrm{CaCO}_{3} \downarrow+\mathrm{H}_{2} \mathrm{O}
\end{gathered}
$$

Urea is needed as primary reagent. If the saturation levels of the calcium carbonate produced are sufficiently high, it will precipitate forming bonds and consolidating its surroundings in the MICCP process. There are bacteria that produce urease in the cytoplasm of the cell for ATP generation. This enzyme hydrolyses the substrate urea. The urease enzyme is non-constitutive in nature, where its activity is independent of urea and ammonia, but varies with the presence of calcium, $\mathrm{pH}$, temperature and calcium nitrate [15], [16].

Urease producing bacteria can be divided into two groups, according to their urease response to ammonium: (i) those, whose activities are repressed by high ammonium concentrations, such as Pseudomonas areuginosa, Alcaligenes eutrophas, Bacillus megaterium and Klebsiella aerogenes, and (ii) those whose activities are not repressed by ammonium, such as Sporosarcina pasteurii, Proteus mirabilis, Proteus vulgaris, Helicobacter pylori, Ureaplasma sp., but some of them are pathogens [17], [18].

Sporosarcina pasteurii was considered the most suitable for the biocementation process as it was the most resistant in alkaline conditions and do not present hazards to the human health. Its favorable growth condition is $30^{\circ} \mathrm{C}$. In order to provide them with oxygen, it needs to be slightly shaken and it needs to be feed with media and urea.

Hydrolysis of urea is an irreversible reaction in which urea reacts with water to form ammonium and carbonate. At neutral $\mathrm{pH}$, bicarbonate $\left(\mathrm{HCO}_{3}{ }^{-}\right)$is the dominant carbonate species rather than carbonate $\left(\mathrm{CO}_{3}{ }^{2-}\right)$, causing a rise in $\mathrm{pH}$ to maintain charge balance. As a result of the $\mathrm{pH}$ increment, ammonium $\left(\mathrm{NH}_{4}^{+}\right)$starts to dissociate to ammonia $\left(\mathrm{NH}_{3}\right)$ until equilibrium is reached between $\mathrm{NH}_{4}{ }^{+} / \mathrm{NH}_{3}$ and $\mathrm{HCO}_{3}{ }^{-} / \mathrm{CO}_{3}{ }^{2-}$ at a $\mathrm{pH}$ of about 9.3. The produced carbonate ions precipitate in the presence of calcium ions and form calcium carbonate crystals, which form cementing bridges between the existing sand grains [8], [12]-[14]. In bacterial cells, such as $S$. pasteurii, they act themselves as nucleation sites, causing localized cementation at specific points that can be controlled; thus forming stronger bonds with the solid grain particles.

To produce a high urease rate, the bacteria need urea and a protein source to grow. This will be assimilated by the bacteria and used as energy for its metabolism and reproduction. For producing bio-calcite grains, the presence of free calcium ions is compulsory as well.

\section{B. Alternative Nutrients for Bacterial Growth}

The cost of well-defined media is prohibitively expensive for large scale cultivation of bacteria. The medium ingredients are a major cost factor, ranging between 10 to $60 \%$ of the total operating costs [13]. Hence, large scale growth media is complex and waste or by-products from different industries should be identified to be used as nutrient substitutes. There are many industrial effluents that are rich in proteins, which if released in the altered form could be hazardous for the environment, so the dual benefits of cost reduction and environment protection are feasible by reusing these wastes.

Low cost substrates are generally subject to lowered quality control and reproducibility. The effects of variable feedstock and additional processing required (e.g. for the presence of insoluble particles, when dissolved in water) should be considered in relation to the application of the enzyme produced.

A reduction in the medium costs without loss of urease activity could be possible by the substitution of laboratory grade nutrient medium with several alternative protein sources such as: 1) yeast extracts and its derivative products (Vegemite $^{\mathrm{TM}}$, Marmite ${ }^{\mathrm{TM}}$, brewery waste yeast, Torula yeast), 2) corn steep liquor (CSL) and 3) dairy wastes and by-products (lactose mother liquor (LML), whey, buttermilk and waste water from cleaning system).

1) Torula or Candida yeast refers to products containing Candida utilis, which have been used commercially for more than 60 years as nutritional supplements in animal feeds [19]. Food grade Torula yeast is cultivated in mixtures of sugars and minerals, usually containing molasses, cellulosic wastes (e.g. spruce wood) or brewing by-products.

The production of dried Torula yeast as waste product results from the fermentation of the waste sulfite liquors "brown liquor" from paper production. The yeast slurry, containing about $1 \%$ solids, is continuously separated from the substrate by centrifuging, the collected yeast cells are washed to remove all adhering chemicals and then dried to a moisture content of $<7 \%$ to give the commercial product. This product has very high protein content (min 45\%) and substantial amounts of B vitamins [19].

Brewery waste yeast is surplus yeast from the brewing process. Low fermentation beer is produced through two fermentation steps: the primary fermentation being when $90 \%$ of the fermentable matter is consumed; the secondary fermentation and maturation, when a rapid cooling of the tank stops fermentation and causes flocculation of insoluble particles and the sedimentation of the yeast. The surplus yeast is recovered by natural sedimentation at the end of this second fermentation process. The tank bottom becomes full of yeast and "green beer". This brewing by-product has dry matter content close to $10 \% \mathrm{w} / \mathrm{w}$ and generates beer losses of between 1.5 and $3 \%$ of the total volume of produced beer. In order to be recovered, the "green beer" needs to be separated from the yeast [19], [20]. However, many breweries, especially smaller ones, discharge all surplus yeast without recovering any entrained beer contributing to considerable sewer loadings.

The amount of yeast grown depends on the fermentation conditions of each brewery, the type of yeast, the glycogen content, etc. Wort constituents that may affect yeast growth include carbohydrates, amino acids, free fatty acids and trace minerals such as zinc. The total mineral content of yeast is approximately $5-10 \%$ of the cell dry weight. This fraction comprises a multitude of elements, especially potassium and phosphorous. The most abundant element in yeast cells is carbon, which accounts for $50 \%$ of the dry weight. Other major elemental components are oxygen (30-35\%), nitrogen 
(5\%), hydrogen (5\%) and phosphorous (1\%). The most abundant classes of macromolecules are proteins and carbohydrates [20].

Due to yeast composition rich in protein, amino acids, minerals, and other compounds of interest, several attempts have been done aiming to reuse the surplus yeast in biotechnological processes as source of nutrients. We have found a reference in the literature to the use of brewery waste yeast for the production of urease activity [19], [20]. Brewery waste yeast is largely comprised of whole cells, which resulted inaccessible to the growing microorganisms. Despite of that, initial attempts to lyse the cells were made by exposing them to $0.5 \mathrm{M} \mathrm{NaOH}$ for 20 minutes, followed by addition of $\mathrm{H}_{2} \mathrm{SO}_{4}$ to neutralise the cell extract to $\mathrm{pH} 8$ [21]. However, this procedure produced an extract, that did not sustain growth of $S$. pasteurii (data not shown) so further investigation is required.

Brewery waste yeast is not recommended as a first option to form an alternative medium for the $S$. pasteurii growth. There are other industrial by-products that better suit with the project requirements.

2) Corn steep liquor (CSL) is a viscous concentrate of corn soluble, rich in vitamins, amino acids, minerals and other growth stimulants. It contains approx. $50 \%(\mathrm{w} / \mathrm{w})$ solids. $\mathrm{CSL}$ is useful as an inexpensive alternative to peptone for a wide variety of microbiological production methods, including fed-batch production of recombinant proteins in E. coli, high density culture of $S$. cerevisiae, and fermentative production of lactic acid. CSL has a $\mathrm{pH}$ of 3.7 to 4.1 and a specific gravity of 1.25 . On the average $6.9 \%$ of the corn solids and $30 \%$ of the corn nitrogen are found in the steep liquor. CSL has a boiling point essentially that of water and the individual constituents of the mixture are highly water soluble nutrients [22]. For this high solubility, little bioaccumulation can be found, though CSL does provide valuable nutrients that are naturally used by organisms for normal cellular subsistence and metabolism.

Achal et al., [23] used this by-product for economization of the microbial calcite technology. Microbiological calcite precipitation was carried out in the CSL medium $(1.5 \% \mathrm{v} / \mathrm{v})$ and standard nutrient broth (NB). The chemical composition of the sample of CSL used consisted of $45-50 \%$ solids, $5.8 \%$ carbohydrates, $24 \%$ proteins, $1.0 \%$ fats, $8.8 \%$ minerals, and trace amounts of vitamins, and commercially available standard nutrient broth (NB) consisted of (g/l) casein hydrosylates 15.0 , peptone 5.0 , and $\mathrm{NaCl} 5.0 \mathrm{~g} / \mathrm{l}$. Corn steep liquor (CSL) was collected from the corn wet milling industry. Both media were supplemented with $2 \%$ urea and 25 $\mathrm{mM} \mathrm{CaCl}_{2}$. The $\mathrm{pH}$ was adjusted to 6.5 with $1 \mathrm{~N} \mathrm{HCl}$ prior to autoclaving without urea and $\mathrm{CaCl}_{2}$. Filter-sterilized urea and $\mathrm{CaCl}_{2}$ were added later.

De Muynck et al., [24] analysed the price of the microorganisms and the price of the nutrients. The calculated price of $1 \mathrm{~kg}$ lyophilized bacteria was about $1,100 €$. The cost of nutrients were estimated to be about $180 €$ per kg. For a successful commercial process, the cost of nutrients is very high, but CSL can be available at a price of about $3 €$ per liter, which is very economic compared to the standard nutrient medium. In conclusion, the performance of CSL was significantly better than standard laboratory nutrients in terms of microbial concrete production. Also, CSL offers an economic advantage over the standard nutrient medium. Moreover, a potential environmental hazard is recycled beneficially. All these suggest that CSL can be used as an alternative nutrient source for biocalcification.

3) Dairy plants are found all over the world, with several production sectors. Each division produces wastewater of a characteristic composition, depending on the kind of product that is produced (milk, cheese, butter, milk powder, condensate).

The alternative nutrients coming from dairy industry selected for biocementation tests were lactose mother liquor (LML), whey, buttermilk and wastewater coming from the cleaning system.

LML is very high strength waste water generated by the lactose manufacturing milk plants. It is the residual liquor left behind after recovery of lactose from concentrated whey permeates. Due to its high strength, it is not easily amenable for treatment to meet the prescribed effluent standards. Every 10 liters of raw milk processed in the milk plant to produce lactose, generates 1 liter of lactose mother liquor. LML has high residual lactose (up to $15 \%$ or more), whey proteins (up to $8 \%$ or more) and milk minerals and the salts (as high as 7\%) hence it cannot be viewed as waste water [24]. Due to high lactose content (15\% or more), LML can be used as a base culture medium for the production of value added products using biochemical conversion process.

MICCP by the bacterium Sporosarcina pasteurii (NCIM 2477) using LML as growth medium was demonstrated for the first time by Achal et al. [25]. The effect of LML as sole source of growing bacterium $S$. pasteurii was investigated and the calcification effect of its usage was compared. LML served as a better nutrient source for the growth of bacteria and also for calcite precipitation as compared to nutrient broth and yeast extract media, which are quite expensive. Calcite constituted $24.0 \%$ of the total weight of the sand samples plugged by $S$. pasteurii and urease production was found to be $353 \mathrm{U} / \mathrm{ml}$ in LML medium. The compressive strength of cement mortar was increased by $S$. pasteurii in all the media used compared to control. No significant difference in the growth, urease production and compressive strength of mortar among the media suggesting LML as an alternative source for standard media.

Buttermilk is a residual product (may even be acid or acidified) of the processing of milk or cream into butter (by continuous churning and separation of the solid fats) [26].

Whey is a by-product obtained during the manufacture of cheese or casein. In the liquid state, whey contains natural constituents (on average $4.8 \%$ lactose, $0.8 \%$ protein and 0.2 $\%$ fats by weight of the product) which remain when the casein and the majority of the fat have been removed from the milk. Whey delivered in liquid state is used mainly for animal feeds [26].

The wash water used to clean the milking equipment, the pipeline and the bulk tank on a dairy farm could be another alternative nutrient for bacterial growth. Usually are used chemical cleaners to penetrate and lift biofilms from equipment surfaces. Modern detergents are a complicated blend of compounds as no single chemical possesses all 
desired detergent properties. The most common chemical cleaners are alkali and acid detergents. Alkaline wastewater was tested in the eco-cement experiments.

After an extensive research work, beside LML, whey and waste water from cleaning system have been identified as the better nutrient sources for the growth of the bacteria and also for the calcite precipitation [27]. These wastes are available around Europe as a by-product of the dairy industries and may have a regular supply.

\section{Alternative Urea Substitutes for the Bioenzimatically Induced Cementation Process}

Apart from the bacteria, urea is needed as well. Urea is a key component used in the biocementation process. At present, the pure chemical form is being used [8], [13], [23], [25].

Urea is a colorless crystalline chemical compound, with formula $\mathrm{CO}\left(\mathrm{NH}_{2}\right)_{2}$, that is the major end product of protein metabolism in man and in other mammals. It can be found abundantly in the urine and faeces. In the industrial sectors, urea is used for many functional uses, e.g. as adhesives, binders, sealants, resins, fillers, analytical reagents, catalysts, intermediates, solvent, dyestuffs, fragrances, deodourisers, flavouring agents, humectants and dehydrating agents, formulation components, monomers, paint and coating additives, photosensitive agents, fertilizers, surface treatment agents. Urea is also the key synthetic ingredient in the manufacture of some medicines. It is also widely used as an animal feed supplement [28].

The amount required for biocementation was outlined by Al-Thawadi [29]. The author suggested that to obtain $1 \mathrm{~m}^{3}$ of bioconcrete (20MPa), the ideal cementation solution concentration was $0.5 \mathrm{M}$ of urea. This caused the precipitation of $145 \mathrm{mg}$ of calcium carbonate per gram of aggregate. Assuming the above, it was estimated that $340 \mathrm{~kg}$ of calcium carbonate were needed per $\mathrm{m}^{3}$. Thus, the urea needed was $204.19 \mathrm{~kg}$.

Alternative sources of urea are the animal manure (i.e. faeces and urine). Urea is one of the major nitrogen excretory products of dairy cattle, sheep and many other large animals and hence, large animal operations located near waterways may be a source of urea. Non-ruminants animals are also a source of this nitrogen nutrient. Uric acid is the primary nitrogen form released by poultry, and the first decomposition product of uric acid is urea. The time scale of conversion from uric acid to urea depends on the microbial activity of the poultry litter and its moisture content [28], [30].

The quantity of manure produced varies considerably among species because of differences in animal diets and metabolism and within species due primarily to differences in management. For example, broiler litter may contain four to five times as much $\mathrm{N}$, and ten times as much $\mathrm{P}$, as horse manure.

Urine could be an alternative urea source but, apart from Urea, it contains pathogens, metals, hormones, chemicals, etc. The presence of these substances in urine was studied with regards to its effects in the bacterial and cementation process. Van Paassen [31], [32] checked these effects and concluded that sodium chloride has similar effect on urease activity as calcium chloride but to a lesser extent. As such it could be regulated and controlled. However, the effects of potassium and other salts present were not investigated by the author. Preferential formation of calcium carbonate or sodium carbonate depended on the third law of thermodynamics. Therefore, Van Passen determined that calcium carbonate was formed, if both sodium and calcium ions were present. Thus the process continued as long as there is sufficient supply of calcium chloride. However, the formation of some sodium carbonate could not be ruled out and further study is needed.

In addition to the agriculture and the anthropogenic uses described above, there are other pathways by which urea reaches both the land and water environments. An important one is sewage, as urea is the major nitrogen component of urine. The extent to which this source of nitrogen is released to the environment depends on the state of the sewage treatment plant, the effectiveness of its mineralization and nitrification processes and the degree of nitrogen removal (reference?).

However, the urea recycled from mammalians livestock and sewage sludge cannot be recommended as alternative urea source to produce eco-cement, as the supply quantity is inconstant, unreliable, and hazardous for the human health. The presence of pathogens adds an extra cost that, in certain cases, can be unaffordable if we want to lessen the process expenses.

Cheaper alternatives were found in the fertilizer industries, such as the fertilizer urea [27] and was therefore considered for the production of eco-cement products. Fertilizers offer a good urea source without the need of being pre-treated. It is clear that they are not industrial by-products but they are cheap (around $6 € / \mathrm{kg}$ ), even when compared with urea rich by-products that require expensive pre-treatments. As a consequence, fertilizers will be the urea source recommended to be used in the eco-cementation process. However, taking into account the negative environmental impact for urea production, an ecological urea has been individuated for the scale-up of the process. It is obtained from the gasification of biomass waste.

\section{Calcium and Silica Sources}

Cement kiln dust (CKD) is a fine powdery material similar in appearance to Portland cement. CKD consists primarily of calcium carbonate and silicon dioxide and high amounts of alkalines, chloride and sulfate. The CKD may result from three different types of operations: long-wet, long-dry, and alkali by-pass with precalciner [33], [34]. For the eco-cement research, the CKD was provided from different cement plant sources: Vassiliko (Cyprus), Holcim (Spain), Selcim (Portugal) and Heidelberg Cement (Germany)

The rice husk ash (RHA) was selected for its pozzolanic property due to the amorphous phase content of the silica. It is obtained by the combustion of rice husk. RHA is a highly reactive pozzolanic material suitable for use in lime-pozzolana mixes and for Portland cement replacement. RHA contains a high amount of silicon dioxide, and its reactivity related to lime depends on a combination of two factors, namely the non-crystalline silica content and its specific surface [35].

The Rice Husk Ash (RHA) was provided from Indian, Spanish and Italian producers. 
Sources of solid waste in cement manufacturing include clinker production waste, the kiln dust removed from the bypass flow and the stack (CKD), and waste generated from plant maintenance (e.g. used oil and scrap metal).
CKD is the dust which passes out of the top of the preheater with the exhaust gases, or more typically out of the back of a long dry kiln. CKD is the only cement waste source with the required calcium content (Fig. 1).

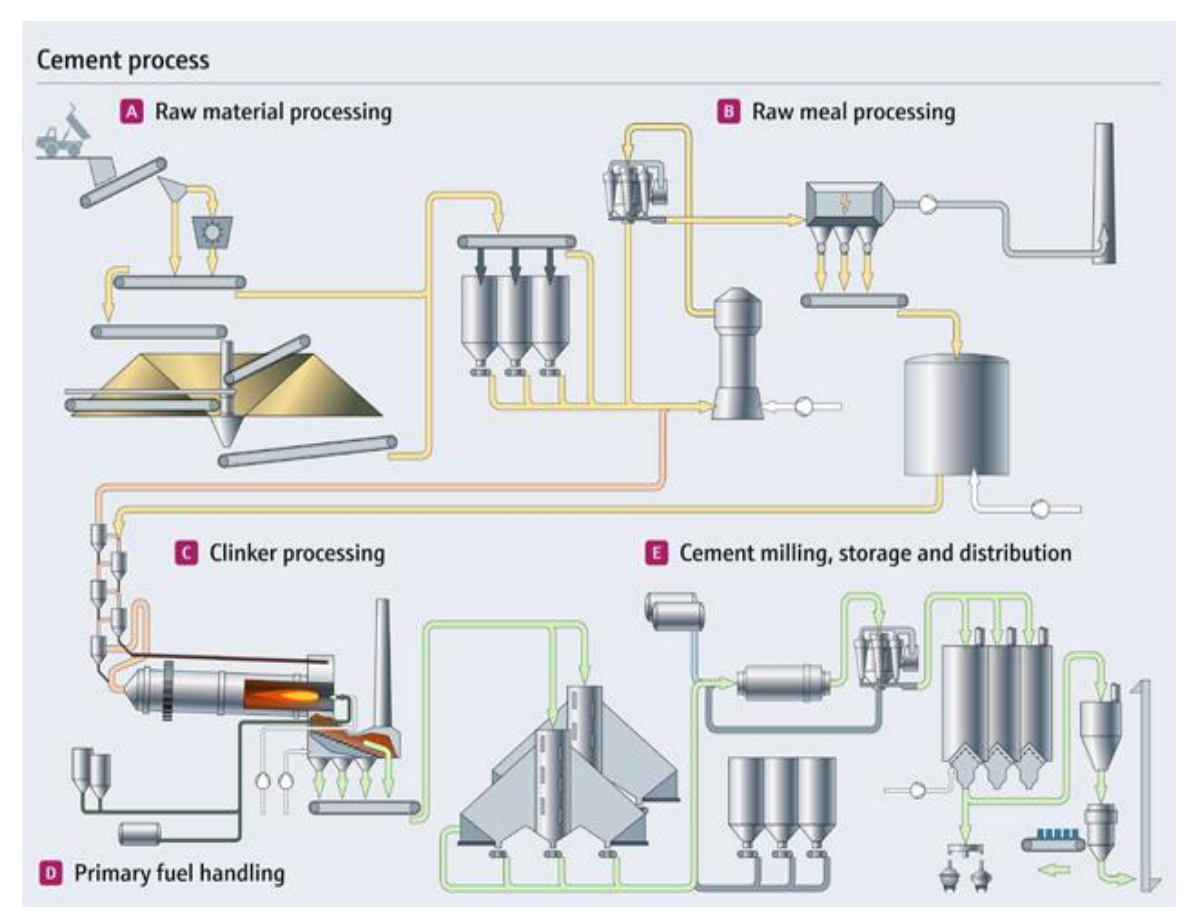

Fig. 1. The cement production and waste stream in the cement plant [36].

The suitability of this product for producing a novel ecological product has been explored. All the examined data indicated that exists no "average" CKD, and that each CKD source should be considered as having its own unique properties. Therefore, multiple samples from different kilns were needed to produce statistically significant results because of the inherent differences between cement plants and within the process of each cement plant, from variations in raw materials, fuels, equipment design, kiln operations, etc. The variability in the composition of CKD, and in particular the large variability in free lime content, highlight the importance of fully characterizing each particular CKD sample before recommending it for reuse as part of the eco-cement process. Preliminary experiments were carried out with samples obtained from Vassiliko Cement plant in Cyprus. The analyses, characterization and testing of these samples have demonstrated, that Vassiliko CKD was not suitable as the calcium source, being it mainly present as calcite, without any presence of $\mathrm{CaO}$ and $\mathrm{Ca}(\mathrm{OH})_{2}$.

The lack of free lime can be attributed to the fact that the Vassiliko sample could have been stockpiled. Once CKD is exposed to moisture, the alkali sulfates are likely to go into solution. Free lime and some cementitious phases, if present, may undergo hydration or carbonation. Thus stockpiled CKD may contain some prehydrated or carbonated lime and hydrated cementitious phase which all may contribute to high Loss of Ignition (LOI) and absence of free lime. Therefore, the fresh CKD sample is preferred.

In parallel, more samples of CKD were collected and tested: two samples from Holcim (Spain) and another two from Heidelberg Cement (Germany). All the experiments have been repeated with these additional sources of CKD.
In particular, the CKD "Bypur" (HeidelbergCement, Germany) showed the highest $\mathrm{CaO}$ content and promising properties as binder for the eco-cement.

\section{Producing ECO-CEMENT WITH WASTES}

The eco-cement process is subdivided into three aspects: (i) preprocess, (ii) process, and (iii) components.

i) The eco-cement preprocesses deal with the $S$. pasteurii bacterial culture preparation, conservation/storage and reactivation.

ii) The eco-cement process is a function of several parameters like the mixture protocol, the curing temperature and humidity, the moulds dimension and material. The process is dependent on the pre-processes and its components.

iii) The eco-cement components are classified in aggregates, binder and liquid. The aggregate selected is the washed sand. The binder consists out of two types of waste: the CKD and the RHA. The liquid contains the S. pasteurii bacterial culture (biomass). Depending on the pre-process, the liquid also may contain the growth medium of the bacteria and urea, or only water and urea.

The preparation of the mixture firstly followed the same ratio used for preparing the standard hydraulic cement (usually 1 binder: 3 aggregate: 1 water), even if in the eco-cement, no binder is present as in the ordinary Portland cement (OPC). Eco-cement is a mixture of bacteria, calcite, lime, silica acid and not reactive compounds. If in the CKD is enough amount of available lime (> 40-50\%), it can be considered as an aerial mortar (binder).

A comprehensive study varying the parameters of the 
recipe was performed. Varying amounts of CKD, RHA, sand, urea concentration and biomass were used in the manufacturing of standard blocks of eco-cement. The final ratios used did not follow the ration of the hydraulic cement as strictly as the variation of a single parameter at a time was essential. Excessive care was given for the wet material to have similar, if not identical, consistency for reproducibility reasons. Five identical blocks corresponding to each recipe were manufactured in order to obtain a good statistical sample. The blocks were poured into $5 \mathrm{~cm} \times 5 \mathrm{~cm} \times 5 \mathrm{~cm}$ moulds. Curing took place under controlled conditions (temperature $30 \mathrm{C}$, humidity $82 \%$ ) in a sealed chamber. After a curing time of 28 days, the blocks were used for a variety of crash tests to gain inside on strength and resistance.

The MICCP process in the presence of industrial waste gives final eco-cement products with three different applications (Fig. 2): (i) plaster, (ii) bedding mortar, and (iii) tiles.

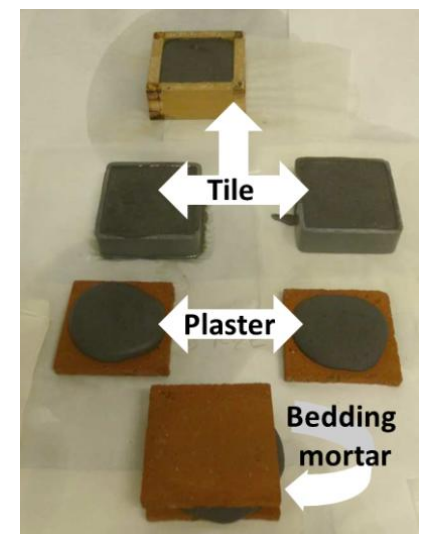

Fig. 2. The eco-cement products.

Consequently the standard test for evaluation of its mechanical properties would be UNI EN 1015-11:20079. Usually the values of mechanical property analysis (MPA) determined in such type of samples are quite lower with respect to those determined in "Portland" concrete or mortar.

A possible alternative for the eco-cement product could be a use as plaster. In this case the standard test is UNI EN 1015-12:200210.

A Life Cycle Analysis (LCA) was carried out to assess the global environmental impact of the project's Eco-Cement, as well as the materials that constitute it, in order to compare it to Ordinary Portland Cement (OPC) and Ecocem Ireland's GGBS product. The system boundaries of the LCA were cradle-to-cradle looking at all possible stages in the life cycle of Eco-Cement. The LCA followed ISO 14040 and 14044 standards using the SimaPro 8.0.2 software, which accounts for impact evaluation methodologies such as Environmental Product Declarations (EPDs), Greenhouse Gas (GHG) protocol, the International Life Cycle Design (ILCD) handbook, ReCiPe Endpoint, Centre of Environmental Science-Impact Assessment (CML-IA), Ecoindicator'99 (E99) among others.

Various environmental impact categories were examined using the predetermined Key Environmental Performance Indicators (KEPI) and functional units (FU) such as: climate change, human health impact, resource depletion, ozone depletion, impact on freshwater and marine ecosystems and impact on terrestrial ecosystems. The preliminary results indicated that the Eco-Cement product and its components created minimal environmental impact overall, displaying positive environmental values in some categories. In comparison to OPC and Ecocem, eco-cement has an environmental impact, which is approximately $77 \%$ lower. Both the significant reduction of energy consumption, as well as the diversion of industrial waste from landfills significantly reduces the overall environmental impact and carbon footprint of eco-cement. This assessment methodology helped the project to identify areas of opportunity to reduce the environmental impact of the process in relation to material selection and processes. For example, the substitution of fertilizer urea with bio-urea made through the gasification of waste biomass was identified and integrated into the final process because of its much lower impact and multiple benefits. Thus LCA was successfully used as an assessment tool and a design tool in this project.

\section{DEMO}

For the large scale production of eco-cement, the fresh CKD, extracted from the by-pass dust stack (Fig. 1) was used, as source of inexpensive calcium. The ureolithic bacteria Sporosarcina pasteurii was fed with dairy industry by-products as nutrients. Urea was obtained from the gasification of biomass waste. In order to increase the hydraulically of the mixture, RHA was added.

The dry biomass can be stored at room temperature for several months. This can be easy revitalized at the moment of use. The revitalization consists in the incubation of the biomass in urea solution $(2 \%)$ at around $30^{\circ} \mathrm{C}$ for $3-4$ hours. All the solid components are therefore mixed thoroughly for a few minutes in a concrete mixer (Fig. 3), adding the urea solution and biological mass after its revitalization and filtering, in order to create a fluid paste with constant amalgamating and slow action.

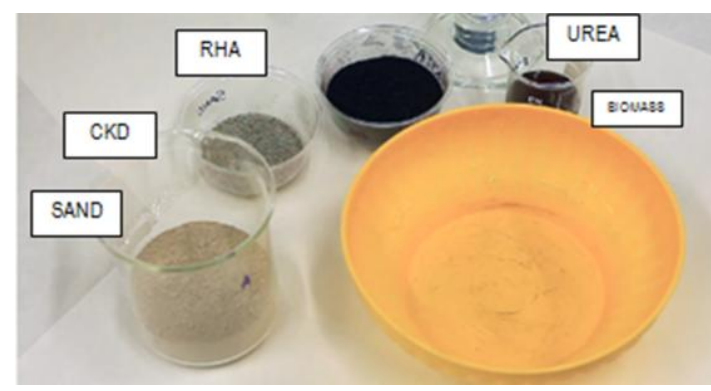

(a)

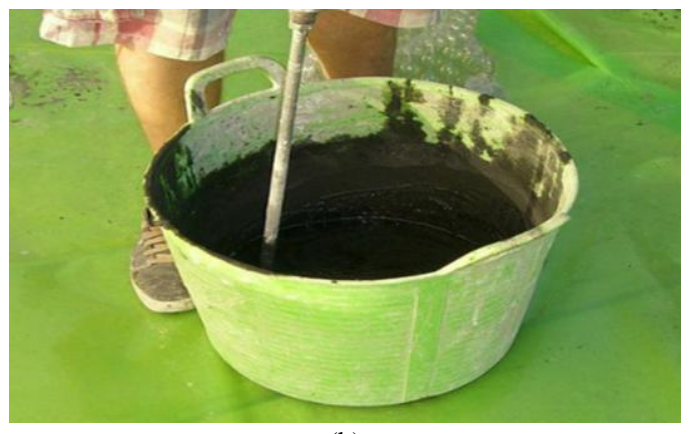

(b)

Fig. 3. The main components of the eco-cement product (a) and mixture preparation (b). 
The mixture can be used as a plaster or bedding mortar. A plaster layer (Fig. 4(a)) of $1 \mathrm{~cm}$ thick for a total of $0.01 \mathrm{~m}^{3}$ was applied by a trowel on a Plaster board $(100 \times 100 \times 1 \mathrm{~cm})$ and a layer ( $1 \mathrm{~cm}$ between the bricks in succession) was applied in order to build a wall (Fig. 4(b)) composed of a column of 3 bricks length and 3 brick height (mortar layer thickness $1 \mathrm{~cm}$ ) for a total of $0.004 \mathrm{~m}^{3}$.

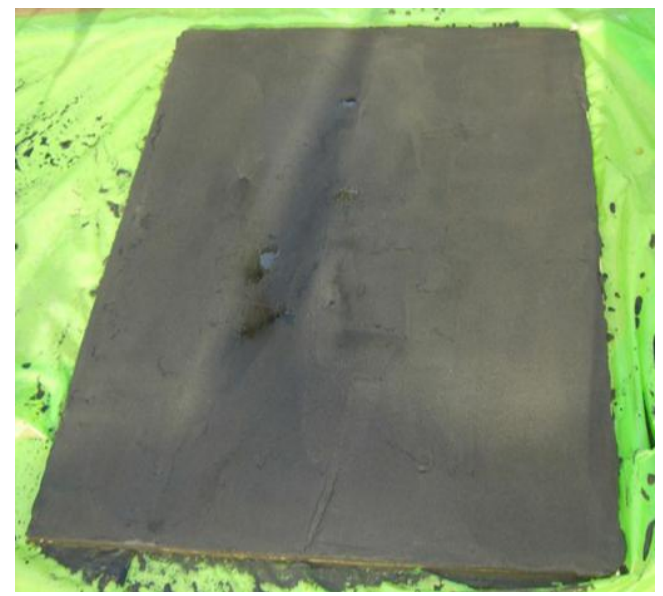

(a)

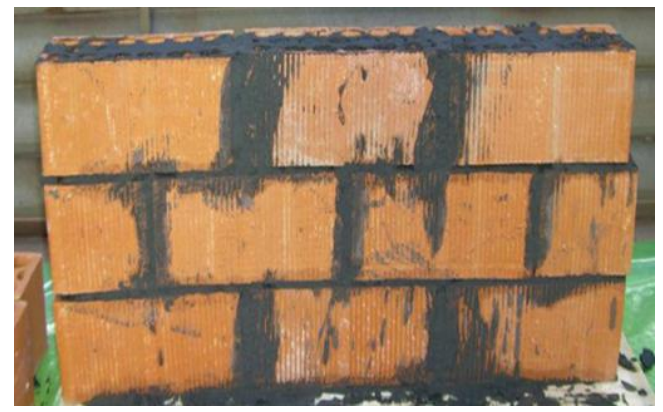

(b)

Fig. 4. The plaster layer (a) and wall bricks (b) constructed with the eco-cement mixture.

\section{ACKNOWLEDGMENT}

This work was made under the frame of the ECOCEMENT project (FP7-Grant 282922). The authors thank to all the collaborators that kindly provided the row materials for testing, and to the other esteemed project partners P. Tiano, S. Rescic, K. Richter, J. Stuart and N. P. Bakas, which contributed to this work.

\section{REFERENCES}

[1] European commission, Set-plan information system (SETIS), Technology Map - Chapter on Energy efficiency and $\mathrm{CO}_{2}$ emission reduction in the Cement Industry, 2002.

[2] M. Taylor, C. Tam, and D. Gielen, "Energy efficiency and $\mathrm{CO}_{2}$ Emissions from the global cement industry," presented at IEA-WBCSD Workshop, Paris, September 4-5, 2006.

[3] W. Michaelis, R. Seifert, K. Nauhaus et al., "Microbial reefs in the Black Sea fueled by anaerobic oxidation of methane," Science, vol. 297, pp. 1013-1015, August 2002.

[4] P. Tiano, L. Biagiotti, and G. Mastromei, "Bacterial bio-mediated calcite precipitation for monumental stones conservation: methods of evaluation," J. Microbiol. Methods, vol. 36, pp. 139-145, May 1999.

[5] P. Tiano, "Biomediated calcite precipitation for monumental stone reinforcement," in "Biodeterioration and its control - biotechnologies in cultural heritage protection and conservation," in Proc. $5^{\text {th }}$ EC Conference, Krakow, May 16-18, 2002, pp. 48-51.

[6] P. Tiano, E. Cantisani, I. Sutherland, and J. M. Paget, "Biomediated reinforcement of weathered calcareous stones," J. Cult. Herit., vol. 7, pp. 49-55, January-March 2006.
[7] C. Barabesi, A. Galizzi, G. Mastromei, M. Rossi, E. Tamburini, and B. Perito, "Bacillus subtilis gene cluster involved in calcium carbonate biomineralization,” J. Bacteriol., vol. 189, pp. 228-235, January 2007.

[8] L. A. Van Paassen, V. S. Whiffin, and M. P. Harkes, "Microbially induced carbonate precipitation as ground improvement technique carbonate precipitation with denitrifying bacteria," Patent WO2007069884, June 21, 2007.

[9] J. P. Adolphe, J. F. Loubiere, J. Paradas, and F. Soleilhavoup, "Procédé de traitement biologique d'une surface artificielle," European patent 90400G97.0, Sept. 19, 1990.

[10] S. Castanier, G. Le Métayer-Levrel, G. Orial, J. F. Loubière, and J. P. Perthuisot, "Bacterial carbonatogenesis andapplications to preservation and restoration of historic property," in Microbs and Art, O. Ciferri, P. Tiano, G. Mastromei, Eds. 2000a, pp. 203-218.

[11] S. Castanier, G. L. Metayer-Levrel, and J. P. Perthuisot, "Bacterial roles in the precipitation of carbonate minerals," in Microbial Sediments, R. E. Riding and S. M Awramik, Eds. Springer-Verlag, Heidelberg, 2000b, pp. 32-39.

[12] J. Dick, W. de Windt, B. de Graef, H. Saveyn, P. Van der Meeren, N. de Belie, and W. Verstraete, "Bio-deposition of a calcium carbonate layer on degraded limestone by Bacillus species," Biodegradation, vol. 17 , pp. 357-367, 2006

[13] V. S. Whiffin, "Microbial $\mathrm{CaCO}_{3}$ precipitation for the production of biocement," PhD dissertation, School of Biological Sciences and Biotechnology, Murdoch University Western Australia, 2004.

[14] Y. Fujita, F. G. Ferris, R. D. Lawson, F. S. Colwell, and R. W. Smith, "Calcium carbonate precipitation by ureolytic subsurface bacteria," Geomicrobiology J., vol. 17, pp. 305-318, October 2000.

[15] K. L. Bachmeir, A. E. Williams, J. R. Warmington, and S. S. Bang, "Urease activity in microbiologically-induced calcite precipitation," $J$. Biotechnol., vol. 93, pp. 171-181, February 2002.

[16] N. K. Dhami, M. S. Reddy, and A. Mukherjee, "Biomineralization of calcium carbonates and their engineered applications: A review," Frontiers in Microbiol., vol. 4, pp. 1-13, October 2013.

[17] M. B. Burbank, T. J. Weaver, B. C. Williams, and R. L. Crawford, "Urease activity of ureolytic bacteria isolated from six soils in which salcite was precipitated by indigenous bacteria," Geomicrobiol. J., vol. 29, pp. 389-395, 2012.

[18] I. Konieczna, P. Żarnowiec, M. Kwinkowski, B. Kolesińska, J Frączyk, Z. Kamiński, and W. Kaca, "Bacterial urease and its role in long-lasting human diseases," Curr Protein Pept Sci., vol. 13, pp. 789-806, December 2012.

[19] A. Bekatorou, C. Psarianos, and A. A. Koutinas, "Production of food grade yeasts," Food Technol. Biotechnol., vol. 44, pp. 407-415, 2006.

[20] S. N. Nigam and P. P. Ashok, Biotechnology for Agro-Industrial Residues Utilisation, p. 466, 2009.

[21] H. Schutte and M. R. Kula, "Pilot- and process-scale techniques for cell disruption," Biotechnol. Appl. Biochem., vol. 12, pp. 599-620, December 1990.

[22] R. S. Daniels, "Corn Step Liquor as a biostimulant composition," Patent number 20120028801, February 2, 2012.

[23] V. Achal, A. Mukherhjee, and S. Reddy, "Biocalcification by Sporosarcina pasteurii using corn steep liquor as nutrient source," Industrial Biotechnol., vol. 6, pp. 170-174, June 2010.

[24] W. de Muynck, N. de Belie, and W. Verstraete, "Microbial carbonate precipitation in construction materials: A review," Ecological Engineering, vol. 36, pp. 118-136, 2010.

[25] V. Achal, A. Mukherjee, P. C. Basu, and M. S. Reddy, "Lactose mother liquor as an alternative nutrient source for microbial concrete production by Sporosarcina pasteurii," J. Ind. Biotechnol., vol. 36, pp. 433-438, 2009.

[26] Glossary. [Online]. Available: http://www.clal.it/en/?section=glossario

[27] O. A. Cuzman, L. Wittig, K. Richter, and P. Tiano, "Alternative nutrient sources for biotechnological use of Sporosarcina pasteurii," Rev. Environ. Sci. Biotechnol., under review, 2014.

[28] Urea. [Online]. Available: http://en.wikipedia.org/wiki/Urea

[29] S. A. Salwa, "High strength in-situ biocementation of soil by calcite precipitating locally isolated ureolytic bacteria," $\mathrm{PhD}$ dissertation, Murdoch University, 2008.

[30] P. M. Glibert, J. Harrison, C. Heil, and S. Seitzinger, "Escalating worldwide use of urea - a global change contributing to coastal eutrophication," Biogeochemistry, vol. 77, pp. 441-463, 2006.

[31] L. A. Van Paassen, "Biogrout-ground improvement by microbially induced carbonate precipitation," Ph.D. dissertation, Delft, The Netherlands, Delft University of Technology, 2009a.

[32] L. A. Van Paassen, M. Pieron, A. Mulder, Van der Linden, M. C. M. van Loosdrecht, and D. J. M. Ngan-Tillard, "Strength and deformation 
of biologically cemented sandstone," in Rock Engineering in Difficult Ground Conditions-Soft Rocks and Karst, Vrkljan, Ed. 2009b, pp. 405-410.

[33] H. A. Todres, A. Mishulovich, and J. Ahmed, "Cement kiln dust management: Permeability," RD103, Portland Cement Association, Skokie, Illinois, USA, 1992.

[34] W. S. Adaska and D. H. Taubert, "Beneficial uses of cement kiln dust," in Proc. IEEE/PCA 50 th Cement Industry Technical Conf., Miami, FL, May 19-22, 2008, pp. 1-19.

[35] M. M. Tashima, C. A. R. Silva, J. L. Akasaki, and M. B. Barbosa, "The possibility of adding the Rice Husk Ash (RHA) to concrete," in Proc. International RILEM Conference on the Use of Recycled Materials in Building and Structure, 2004, pp. 1-9.

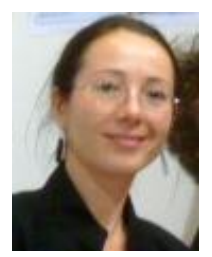

Oana Adriana Cuzman was born in Romania in 1978. She received a bachelor of science degree in ecology and environmental protection from University "Al. I. Cuza" Iassy, Romania, in 2000, and a $\mathrm{PhD}$ degree in science for conservation within the frame of EPISCON Project, in October 2009 at University of Bologna. She works as a researcher at Institute for Conservation and Valorization of Cultural Heritage, CNR-ICVBC, Florence, Italy, for the last 5 years. Her research interests are the control of biological growth on monumental stones, the study of biodeterioration phenomena on cultural heritage assets, the biotechnological use of microorganisms in cultural heritage and environmental fields, the waste minimization, recycling and reuse.

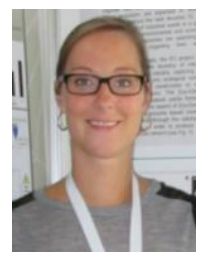

Linda Wittig was born in Bremen, Germany on the 31th of July, 1983. She has a MSc degree in technical and applied biology and is a scientific member of the working group "Bioinspired Material - BiMa" at the Fraunhofer IFAM since 2007. During her master thesis in 2010, she investigated the activity of antimicrobial agents/coatings. Additionally, she is experienced in analytical microbiology (e.g. fluorescence microscopy, multimodereader), protein analysis (e.g. with QCM-D), as well as biofunctionalisation of surfaces and test design for microbial investigations.

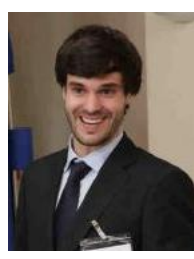

Francisco Javier Royo Abancéns was born in Zaragoza, Spain in 1988. He is a civil engineer graduated with honors in 2011 from Idaho State University, Pocatello, USA. Mr. Royo held a master degree in 2014 in engineering of structures, footings and materials from the Polytechnic University of Madrid, Madrid, Spain.

$\mathrm{He}$ is currently employed at Solintel M\&P, Madrid, Spain, where he acts as a project manager and research

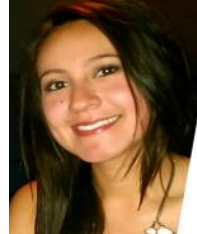

Catalina Herrera was born in Bogota, Colombia in 1989. She moved to Toronto, Canada with her family at an early age. Catalina completed her B.Sc. Honors in environmental science at Queen's University in Kingston, Ontario, Canada in 2013. After a brief spell working with the Ontario Ministry of Natural Resources (MNR) in Peterborough, Ontario, as a water resource technician, she moved to Dublin, Ireland where she undertook her M.Sc. degree in environmental resource management in University College Dublin (UCD).

Catalina was previously a research assistant for the Ecology Laboratory at UCD and is currently working as an environmental consultant for Delap \& Waller EcoCo: Integrated Sustainable Design Consultants, in Dublin Ireland, carrying out life cycle assessments (LCAs).

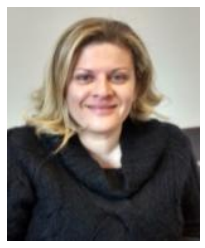

Natia R. Anastasi is of Cypriot background and was born in Moscow, Russia in 1975. She received a bachelor of science degree with highest honors from the University of Virginia in the USA in 1997, and a PhD degree in Organometallic Chemistry from Yale University in 2002, under the supervision of Prof. John F. Hartwig. Her PhD thesis described extensive studies on the borylation of hydrocarbons, a reaction that is a rare example of hydrocarbon activation.

After a post-doctoral fellowship at the University of Wisconsin, Madison under the supervision of Prof. Shannon S. Stahl, she returned to Cyprus where she has been working in the local industry for the past ten years. She is currently a senior chemist at A.N.C. Waterproofing Industries, a company which manufactures bituminous products for the construction and road construction industries. Since June 2014. She also serves as an external scientific consultant at Neapolis University, Pafos.

Dr. Anastasi has numerous publications in scientific journals and has served on various committees as a scientific expert both in Cyprus and overseas.

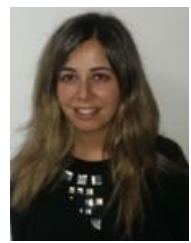

L. Sánchez Alonso holds a degree in mining engineering and works as a engineer and R\&D consultant inside Essentium Group. Ms. Sánchez has more than 4 years' experience in the management, planning, execution and control of quarry operations and 4 years' in the coordination of European research and development funded projects. Currently, she is the project coordinator of 2 funded FP7 projects, one focused on the construction sector and energy efficiency for industrial facilities, and the other one on the development of ecological and low carbon emission construction material.

engineer. 